\title{
A New Model of Petrochemical Technology Strategic Planning
}

\author{
Maryam Ebrahimi \\ School of Business and Economics, Tarbiat Modares University \\ PO box 14115-111, Jalal Ale Ahmad Highway, Tehran, Islamic Republic of Iran \\ Tel: 98-21-8806-3104Ｅ-mail: mar.ebrahimi@gmail.com \\ Abbas Moghbel Baerz (Corresponding author) \\ School of Business and Economics, Tarbiat Modares University \\ PO box 14115-111, Jalal Ale Ahmad Highway, Tehran, Islamic Republic of Iran \\ Tel: 98-21-8288-4637 E-mail: moghbela@modares.ac.ir \\ Seyed Hamid Khodadad Hosseini \\ School of Business and Economics, Tarbiat Modares University \\ PO box 14115-111, Jalal Ale Ahmad Highway, Tehran, Islamic Republic of Iran \\ Tel: 98-21-8288-4673 E-mail: khodadad@modares.ac.ir
}

Adel Azar

School of Business and Economics, Tarbiat Modares University

PO box 14115-111, Jalal Ale Ahmad Highway, Tehran, Islamic Republic of Iran

Tel: 98-21-8288-3609Ｅ-mail: azara@modares.ac.ir

Received: December 31, 2012

doi:10.5430/ijba.v4n2p57
Accepted: February 27, $2013 \quad$ Online Published: March 14, 2013

URL: http://dx.doi.org/10.5430/ijba.v4n2p57

\begin{abstract}
We, for the first time, propose a new model for technology strategy formulation in Iran's petrochemical industry. It is the result of an integrated and systematic hybrid of existing models presented in literature of technology strategy. Furthermore, we identify strategies of technology development in Iran's petrochemical industry by using ability attractiveness matrix and patent indicators. A list of technologies in the industry, the industry's ability in the development of technologies, attractiveness of technologies in the industry, and patent indicators in the evaluation of the industry are identified based on experts' viewpoints. Data is collected in subsidiary companies. Respondents are professional employees in these companies doing research in specific fields of petrochemical industry.
\end{abstract}

Keywords: Research, Investment, Knowledge, Critical technology

\section{Introduction}

Technology plays a crucial role in competitions. Global market and a shorter life cycle for technologies, today lead developing countries to face greater challenges in developing their industries (Kartiko et al, 2003); for decades, technological changes and innovations, driven by research and development have been the most important sources of productivity growth and increased welfare (Edquist, 2000). Developing countries import technologies; however, a certain amount of R\&D capacity is necessary in the host economy for absorbing them i.e. the imported technologies should be adapted to local conditions applied for alternative uses.

Technological competencies, amount of investment, technology sourcing and competition need to be managed based on a strategic point of view. The first and most important step of technology management is to develop a long-term strategic plan which determines firm's investment priorities and preferences in the field of technology development, 
called "Technology Strategy" (TS) (Arasti and Packniat, 2011). TS is a concept dates back to the period of World War II, when Westinghouse and General Electric companies, in their diversification process, implemented a planning strategy to manage their technology and development activities (Henderson, 1989).

There are some inconsistencies in using the terms: national TS, firm's TS, national technology policy, and national priorities of technologies.

Ford (1988) defines TS as an aspect of business strategy which is concerned with exploiting, developing, and maintaining the sum total of the company's knowledge and abilities. Vernet and Arasti (1999) refer to TS as the firm's priority in technology development directing the firm's future directions in technology issues. Firm's TS is a model of managerial decisions pertaining to the use of principal technology tools and targets in achieving business objectives and prioritizing future corporate technological plans (Ghazinoory et al, 2009).

Chang (2002) states that national technology policy is a set of government actions that affect production, acquisition, adaptation, diffusion, and use of technological knowledge that the government rather than individuals recognizes them useful for the society (Ghazinoory et al, 2009, 836).

National priorities of technologies are one of the steps in national TS. There are different methods to assess and identify national technology priorities. One of the most practical methods which is widely used in several countries, e.g. United States, France and recently in Iran, is the method of critical technologies. This method presents the matrix of feasibility-attractiveness whereby technologies are prioritized based on feasibility and attractiveness features (Klusacek, 2011; Ghazinoory et al, 2009).

In Iran's petrochemical industry (IPI), national TS can be defined as follows:

National TS refers to an integrated set of tasks and responsibilities in each planned technology area based on technology abilities and attractiveness to achieve defined goals.

To promote the production of petrochemical products in Iran, to hold a worthy position in the world, and to satisfy the need for "oil-free economy", the petrochemical industry strategic development plan is provided with regard to appropriate quality and quantity of accessible feed and potential need for domestic and export products. This plan has suggested constructing thirty petrochemical production complexes in five phases, whereby a high level of average annual profit and job creation is forecasted (planning and development division of National Petrochemical Industries Co., 2003). Successful implementation of this plan is subject to acquire international experiences in technology and IPI cooperation with foreign companies.

Based on literature review, this paper introduces TS concept and suggests an integrated and comprehensive model for making TS in IPI. According to the suggested model, a technology tree based on petrochemical industry strategic development plan and forty experts' viewpoints is defined, prioritized, and analyzed for strategy formulation in each technology.

\section{Models of TS Formulation}

There are extensive range of techniques and mechanisms which are used for development of strategies for technological progress. Models of TS formulation can be categorized from multiple perspectives. For example models can be either company level or national based on the areas of study. In addition, according to the approach adopted for TS formulation, models can be classified as decision matrices based models and process based. Besides, in relation to the specificity of TSs, models can be arranged as general TS and partial TS. Different perspectives and researches of the models of TS formulation are shown in Figure 1.

$<$ Insert Figure 1 Here $>$

Several studies have been conducted in the field of TS. There are some examples as follows:

(1) Formulating national strategy of nanotechnology proposed by Ghazinoory et al (2009). They proposed their model using STEEP analysis, SWOT analysis, critical technologies, and technology planning approach.

(2) TS formulation in Saudi Arabia, Sudan, and Sri Lanka (Al - Saud, 2009) conducted through SWOT analysis in order to formulate TS at the national level.

(3) Nano - composite strategy in Iranian companies (Ghazinoory and Farazkish, 2010) proposed by using Chiesa model for TS formulation at the corporate level.

In this paper, the methods used for TS formulation are compared according to the system's viewpoint (input process - output). Techniques of formulating TS are shown in (Table 1). 
<Insert Table 1 Here>

For providing general strategy, there is already a SWOT-based technological strategy planning in IPI. In this study, a new comprehensive model is presented to put forward TS planning in order to complete the current general strategies. This model is according to models: 1) critical technologies approach, 2) technology planning approach, 2) a model described by Yu and Lo (2009), and 3) a model proposed by Ernst (2003), with some changes. The strategies aim to achieve industry's goals. These goals are as follows:

(1) To increase the value of petrochemical products,

(2) To increase the production of methanol and polymer,

(3) To increase the market share,

(4) To increase domestic and foreign private sector investment share,

(5) To increase the export share of petrochemical products among non-oil exporting countries,

(6) To deploy and develop new technologies in the petrochemical industry,

(7) To extend partnerships with other countries in constructing petrochemical plants,

(8) To increase the production of petrochemical products with higher value,

(9) To increase the use of information technology in management and production,

(10) To increase the share of GDP in petrochemical industry,

(11) To expand and deepen research,

(12) To improve human resource development in petrochemical sector.

Critical technologies approach: The main objective of preparing a list of critical technologies is adoption of a clear set of policies that lead the goals to be implemented. In this case, two parameters, attractiveness and feasibility (CSIRO cited by Parsian Puya Mehr Co., 2009) or importance and likelihood (Millenium Project ctited by Klusacek, 2011) were used. The attractiveness of a technology is determined by its potential socio-economic benefits as well as scientific and technological opportunities it could provide. The feasibility feature of a technology is identified according to research and technology potential, and the social awareness for effectively utilizing the new technology (Ghazinoory et al, 2009, 837). This model is applicable at the firm and national level.

$<$ Insert Figure 2 Here $>$

Technology planning approach: The use of strategic decision matrix is often emphasized by this approach. One of the popular models in this field uses the two-dimensional matrix of ability - attractiveness. In general, this method includes the following four steps (Ghazinoory et al, 2009, 837):

(1) Defining important technologies,

(2) Evaluating firm's ability in relation to identified technologies,

(3) Evaluating the attractiveness of determined technologies,

(4) Making a decision matrix and locating technologies in the matrix based on evaluations in the previous steps (Figure 3).

$<$ Insert Figure 3 Here $>$

(1) Scanning - This means that industry should know the latest development and update its expertise though there is no tendency for technology commercialization in these areas, instead of abandoning them.

(2) Replacement- Industry should be on the lookout for the new technologies and replace technologies with more attractive domestic or foreign ones. It is recommended that applied researches should be conducted for localization and development of more attractive technologies and market entry of these technologies.

(3) Development - Industry should realize the causes and factors related to technology deficiency and should formulate and execute appropriate plans to enhance industry's technological ability. In order to develop activities related to these areas, it is recommended to conduct applied research.

(4) Position protection -Industry should harmonize domestic technological changes with global advances according to the subject, and the aim of conducting basic research in order to initiate major achievement and create technology. 
(Ghazinoory et al, 2009)

This model is applicable at the firm and national level.

\subsection{Patents Role in TS Formulation}

A patent is a contract between an inventor and the government, whereby in return for full public disclosure of an invention, the government grants the inventor the right to exclude others for a limited time from making, using, and selling the invention (Hufker and Alpert, 1994). In 1965, Frederic Scherer drew economists' attention to the importance of patent data as output indicators of industrial innovation in industry (Reitzig, 2004).

The patent databases offer valuable information for TS planning. Patent analysis techniques are widely adopted in planning the company's technological innovation strategies. Patents are the most widely available indicator of technological activities gain. There are several indicators which have been found useful to plan the TSs of a company (Yu et al, 2009; Ernst, 2004; Ernst et al, 2006; Chen and Cathy Lin, 2005; Kürtössy, 2004).

We selected two following indicators which are approved to measure technology ability and attractiveness:

(1) Number of declared patents - the number of inventions which received register No. from international patent databases. Thus, distribution across each technology, research and development activity of industry and investment in each technology area of the industry are determined.

(2) Patent Growth - the change in the number of patents from one time period to another, increasing of which indicates emphasis on technologies.

A matrix based on two mentioned indicators is proposed according to TS planning model described by (Yu et al, 2009).

$<$ Insert Figure 4 Here $>$

(1) Technology agreement - industry should procure licenses from the technology leaders.

(2) Mutual licensing - in this case, two companies or governments mutually licenses technologies to each other for common interests.

(3) Technology protection - a strategy that concentrates on patenting and develops patents to protect intellectual properties.

(4) Basic technologies development - this strategy is appropriate for industries that are leading in the technology and emphasize on leadership. In this case, industry allocates its sources to basic technologies from which all technologies are originated.

According to TS planning model described by Ernst (2003), a matrix based on two mentioned indicators is proposed.

$<$ Insert Figure 5 Here $>$

(1) No investment - means to minimize investments and a rigorous process to justify correct operation.

(2) Selective investment - means to retain current programs and allocate investments for technologies which have low risk and high profitability.

(3) Investment - means to make investment in order to maximize growth and promote technologies' position.

\subsection{Ability - Attractiveness Indicators}

In this study, primary indicators for IPI ability in each technology (ability feature) and attractiveness of IPI technologies (attractiveness feature) are presented through indicators extracted from several researches and patent indicators showed in (Table 2).

$<$ Insert Table 2 Here $>$

\section{TS Planning in IPI}

Our model is an integrated and systemized compound of existing methods. It should be noted that no mechanism or a specific model has already been devised for TS formulation in IPI.

The suggested model is shown in (Figure 6) which can be described in four steps.

$<$ Insert Figure 6 Here $>$

Step 1- Preparation of technology areas and existing TS in IPI: at first, the list of different areas of technology is prepared based on petrochemical industry strategic development plan and experts' viewpoints. 
Before presenting technology tree of IPI, it is necessary to deal with the definition of technology in this research. There are various definitions about technology: Pieterse (2001) and Pretorius (2001) refer to the technology triangle and describe technology as the integration of people, knowledge, tools, and systems with the objective to improve people's lives. Khalil (2000) defines technology as hardware, software, brain-ware and know-how. He describes technology as all the knowledge, products, processes, methods and systems employed in the creation of products or in the provision of services. Vernet and Arasti (1999) divide technology into four components: 1) technoware i.e. machines, tools, and equipments, 2) humanware i.e. human skills and experiences, 3) infoware i.e. information, standards, and procedures, and 4) orgaware i.e. business infrastructure and managerial systems.

In this study, technology is defined as all the main knowledge, products, processes, and methods employed in the creation of products or in the provision of services which is classified in (Table 3).

$<$ Insert Table 3 Here $>$

General strategies in IPI are as follows:

(1) Dynamic planning to become producers of knowledge and technology,

(2) Intellectual property management,

(3) Human resources development,

(4) To develop organizational mechanisms and approaches to create the optimal value for stakeholders with the goal of financial independence and income increase,

(5) Commercialization,

(6) To develop participatory model of leadership,

(7) To develop supporting units for research and technology,

(8) Knowledge management to become the knowledge reference of industry,

(9) To develop the synergy between research and education,

(10) To develop strategic management.

Step2 - input analysis: in this step, indicators of ability, attractiveness, and patents are determined for studying the level of industry's ability to develop and use such technologies, attractiveness of technologies in industry, and industry's patenting. The final indicators were identified through reviewing literature and collecting data by utilizing a systemized questionnaire. Then, the significance of indicators in technologies is identified through experts' viewpoints. The scores of the status of the ability indicators and attractiveness in the industry are shown in (Figure 7 and Figure 8).

The final indicators of IPI ability in each field are as follows:

(1) Access to the knowledge with commercial capability in the field of the technology

(2) Comparative position of the patents declaration in the field of technology in IPI against the entire patents'declaration in the field of technology in the international patent databases

(3) Capability of penetration in global market in the technology

(4) Government's support in policymaking

The final indicators of IPI attractiveness in each field are as follows:

(1) Impact of technology on improving customer and society welfare

(2) Impact of technology on expanding local, regional, and international markets

(3) Technology compliance with the allocated budget in research, technology and production

(4) The growth rate of patents in the field of technology in IPI (in the international patent databases)

(5) Technological priorities.

Step 3- Determining the position of technology in petrochemical industry: The condition of technologies in defined matrixes are indicated based on experts' scores for indicators. The obtained conditions of technologies in the research and investment matrixes are shown in (Figure 9 and Figure 10).

Step4 - Determining the validity of the defined strategies: To examine the validity of the determined strategies, a questionnaire including the proposed strategies for each technology were completed by the experts. It proves that all 
of the TSs have (mean $>3)$ and $($ std $<2)$.

In the present research, TSs are derived through a technology planning approach, in which the use of a decision matrix is often emphasized. Due to the importance of research, investment, and protection of the achievements related to technology, three kinds of decision matrices are considered. A consensus strategy that delivers results for each technology of the three matrices will be the TS of that technology.

In the proposed model, indicators of the ability and the attractiveness as well as patent are used as components of the TS. In the existing TS models, the ability and attractiveness are commonly used for TS. In few studies, patent indicators have been used in TS planning. Until now, in researches on TS, the ability, attractiveness and patent indicators all together have not been used to develop a TS.

In the existing TS models, only one decision matrix is used to recommend TS for each technology. This decision matrix proposes TS related only to research, investment, or technology procurement. In the present study, three decision matrices are used simultaneously; and the aggregation of research strategies, investment and technology protection for each technology is recommended. There was not any decision matrix concerning protection strategies in TS literature, however in this research, technology protection strategies based on literature are presented to show how to protect technologies.

In TS models, usually mechanism of strategies validation is not presented. In a model such as national nano technology strategies in Iran for strategies validation, national nano - technology strategies of other countries are used. This method is not right, because TSs in each country are proposed based on country's own specific conditions. In this research, viewpoints of experts in the field of TS are used for TSs validation.

The proposed model also includes the advantages of TS itself. These advantages are as follows:

(1) To determine the list of petrochemical technologies and their classification,

(2) To prioritize technologies and clarify critical technologies,

(3) To propose TS for each technology,

(4) To define indicators of ability and attractiveness specified for IPI,

(5) To determine the status of ability, attractiveness, and patent indicators in IPI.

The model of IPI TS planning presented in the present study is a new method in this field. This method is the most appropriate one because it:

(1) follows the general direction of the country's twenty-year vision,

(2) decreases dependence on natural resources,

(3) reduces the threats of international sanctions on technology,

(4) investigates technological deficiency and identifies areas of technology,

(5) changes business environment and the necessity of reviewing goals and strategies,

(6) and it supports privatization and growing competition between companies in petrochemical industry.

IPI TS planning considered in the present study is also a new method in resolving the following difficulties:

(1) Not profit-based strategies of petrochemical industry,

(2) Lack of technological strategies in petrochemical industry,

(3) Static viewpoint on the issue of technology and lack of knowledge in new technologies in the world,

(4) Unfamiliarity of petrochemical industry with various technologies available in the world,

(5) So many repeated researches that consequently lead to outdated technologies,

(6) Unrealistic outlook of managers to researches,

(7) Lack of attention to infrastructure of technology sales and marketing,

(8) Many research projects offered according to informal relations,

(9) Lack of knowledge in localizing imported technology,

(10) TSs based upon improperly selected features. 


\subsection{Sampling Method}

The survey data has been collected from researchers of the subsidiary companies. these scholars do research in specific fields of petrochemical industry more than five years, have knowledge in these fields, and have higher educational degree in master and $\mathrm{PhD}$. Forty experts participated in data collection.

\subsection{Data Collection Tools}

The research obtains the data using three structured questionnaires and structured interviews. In the first step of the proposed model, the list of different areas of technology is prepared through the structured interview. The three questionnaires are utilised to achieve the following objects in the second and fourth steps:

(1) "To determine ability, attractiveness, and patent indicators in the technology fields of IPI" (used in the second step),

(2) "To identify the status of the ability, attractiveness, and patent indicators in each technology of IPI" (used in the second step),

(3) "To determine the validity of the TSs in IPI and orientation of the strategies" (used in the fourth step).

\section{Conclusion}

Research is emphasized in all technology areas considering the results of the questionnaire of "to determine the validity of the TSs in IPI and orientation of the strategies", prove that TSs in IPI are considered as research oriented with an average total of 2.94 and standard deviation less than one (that are appropriate amounts).

$<$ Insert Figure 9 Here $>$

There are only 16 technologies that need investment in new plans. Therefore, investment is needed to maintain and develop existing programs for other technologies. In other words, investment in new programs is recommended for only 29 percent of technologies; however, other technologies need investment to maintain and develop their existing programs. The results of the questionnaire of "to determine the validity of the TSs in IPI and orientation of the strategies ", prove that TSs in IPI are considered as investment oriented with an average total of 3.31 and standard deviation less than one (that are appropriate amounts).

$<$ Insert Figure 10 Here $>$

To recognize whether TSs in IPI are knowledge oriented or not, knowledge driven strategies decision matrix is used. This matrix is according to the patent status of petrochemical industry in international patent databases. As there are different terms and patterns in patent registration and patent report, the patent status shows the knowledge status of researchers. Therefore, if the invention can not be even commercialized, at least it improves the knowledge of the researchers and the ones who read the reports.

Knowledge driven strategy decision matrix is only used for the technologies for which research and investment are recommended. For only 16 technologies of the 54 technologies, patent information is provided as inputs into the knowledge driven decision matrix. In other words, knowledge based strategy is emphasized for only 29 percent of technologies. Among these 16 technologies, only 9 technologies are considered as the new technology categories: nano-technology, bio-technology, and membrane. It means that high knowledge based strategy is recommended for just 16 percent of technologies. The results of the questionnaire "to determine the validity of the TSs in IPI and orientation of the strategies ", prove that TSs in IPI are not high knowledge oriented and have the average total of 1.79 and standard deviation less than one.

The scores of the ability indicators for nanoparticles and nanocomposites, direct esterification of (PTA) with (EG) and polycondensation, and process of sulphur show that they all are the technologies in IPI with the ability higher than five.

$<$ Insert Figure 7 Here $>$

The results also show that the attractiveness of technologies in IPI including nanoparticles and nanocomposites, direct oxidation, low pressure, liquid phase, steam cracking, PDH, nanocoatings, nanocatalyst, bioremediatiams, biological wastewater treatments, gas separation, liquid separation, membrane synthesis (gas separation), membrane synthesis (liquid separation) are more than five.

$<$ Insert Figure 8 Here $>$

The research results suggest that position protection, technology agreement, and investment are appropriate just for nanoparticles and nanocomposites are the only critical technologies in IPI. Industry should harmonize domestic 
technological changes with global advances and basic researches which aim at initiating major breakthrough and creating technology. It should make investment for promoting growth. An industry should procure licenses from the technology leaders, whenever it needs more advanced technologies.

Dominant strategies in IPI are prioritized as: scanning and no-investment, technology agreement, and selective investment.

Development, technology agreement, and selective investment are proposed for direct oxidation, low pressure, liquid phase, steam cracking, PDH, nanocoatings, nanocatalyst, bioremediatiams, biological wastewater treatments, gas separation, liquid separation, membrane synthesis (gas separation), membrane synthesis (liquid separation). Industry should conduct applied research for promoting these technologies. Additionally, industry should invest for technologies with low risk and high profitability as well as retaining current projects. As the cost of technology development is high, instead industry should procure licenses from the technology leaders.

Replacement, Technology agreement, Selective investment are proposed for direct esterification of (PTA) with (EG) and polycondensation, and process of sulphur. Industry should conduct applied research in order to localize and promote more attractive technologies and market entry of these technologies. Additionally, industry should invest for technologies with low risk and high profitability as well as retaining current projects. As the cost of technology development is high, instead industry should procure licenses from the technology leaders.

Based on these findings, the authors believe that inappropriate mechanism for determining TSs make IPI not act so effectively in allocating its resources to technological projects. For example according to findings, IPI should focus on scanning or not investing. Notably, researches on IPI show that many resources are wasted on some technologies, therefore, industry should stop investing on them.

Determining TSs help decision makers to understand the shortcomings better and solve the problems more efficiently. For example according to findings, IPI should focus on technology transferring. This helps IPI to acquire technical knowledge, improve some other set of quality standards, ensure the products' quality, and transfer knowledge and experience of foreign design engineers and researchers to Iranian ones. Policy makers should focus on improving relationships with other governments and find ways to access leaders' technology licences.

IPI should increase its funds on new technologies categorized into nanotechnology, biotechnology, and membrane. In addition, paying low attention to any of these technologies will make development of economy, society, and environments difficult.

IPI should revise petrochemical industries strategic development plan and choose strategic and attractive technologies. They can try to support the research and development through the findings of this research.

\section{References}

Arasti, M. R., \& Packniat, M. (2011). A classification of models for technology Strategy formulation. International Association for Management of Technology. [Online] Available: http://www.iamot.org/conference/index.php/ocs/9/paper/view/1886/885/ (August 17, 2012)

Arasti, M. R, \& Vernet, M. (1997). Business Process Reengineering: a Systematic Approach to Link Business Strategy and Technology Strategies. Proceeding of the Portland international conference on management engineering (PICMET'97), 57-60.

Burgelman, R. A., Christensen, C. M., \& Wheelwrigh, S. C. (2008). Strategic Management of Technology and Innovation. New York: McGraw-Hill.

Cardullo, M. W. (1996). Introduction to Managing Technology. New York: John Wiley \& Sons.

Chen, D. Z., \& Cathy Lin W. Y. (2005). Essential Patent Indicators for the evaluation of industrial technological innovation competitiveness. Proceedings of ISSI, 490-498. [Online] Available: http://iip.nccu.edu.tw/iip/NEW-iip/IPVAS/Essential\%20Patent\%20Indicators\%20for\%20the\%20Evaluation\%20of\% 20Industrial\%20Technological\%20Innovation\%20Competitiveness.pdf/ (May 23, 2012)

Chiesa, V. (1996). Towards a New Framework for Technology Strategy Formulation. Proceedings of the 3rd International Product Development Conference, 165-178.

Chiesa, V. (2001). R\&D Strategy and Organization. London: Imperial College Press.

Edquist, C. (2000). Systems of Innovation Approaches - Their Emergence and Characteristics. In C. Edquist, and M. McKelvey (Eds.), Systems of Innovation: Growth, Competitiveness and Employment (p.38). UK: Cheltenham Edward Elgar. 
Ernst, H. (2003). Patent Information for Strategic Technology Management. World Patent Information, 25, 233-242. http://dx.doi.org/10.1016/S0172-2190(03)00077-2

Fabry, B., Ernst, H., Langholz, J., \& Koster, M. (2006). Patent portfolio analysis as a useful tool for identifying R\&D and business opportunities - an empirical application in the nutrition and health industry. World Patent Information, 28, 215-225. http://dx.doi.org/10.1016/j.wpi.2005.10.004

Floyd, C. (1998). Managing technology for corporate success. Aldershot: Gower.

Ford, D. (1988). Develop your technology strategy. Long-range planning, 2, 85-94. http://dx.doi.org/10.1016/0024-6301(88)90109-4

Ghazinoory, Divsalar, A., \& Soofi, A. S. (2009). A new definition and framework for the development of a national technology strategy: The case of nanotechnology for Iran. Technological Forecasting \& Social Change, 76, 835-848. http://dx.doi.org/10.1016/j.techfore.2008.10.004

Hax, A. C., \& Majluf, N. S. (1996). The Strategy Concept and Process: A Pragmatic approach. New Jersey: Prentice Hall.

Henderson, B. D. (1989). The Origin of Strategy. Harvard Business Review, 139-143. [Online] Available: http://www.abo.fi/ mbrannba/GSM/henderso.pdf (July 3, 2012)

Hufker, T., \& Alpert, F. (1994). Patents: a managerial perspective. Journal of product and Brand Management, 3 , 44-54. http://dx.doi.org/10.1108/10610429410073138

Jolly, D. R. (2008). Chinese vs. European views regarding technology assessment: Convergent or divergent? Technovation, 28, 818-830. http://dx.doi.org/10.1016/j.technovation.2008.09.001

Kartiko, P., Don, S., Graham, M., \& Roos, D. (2003). Implementing a technology strategy in developing countries The experience of the Indonesian rolling stock industry. Technological Forecasting \& Social Change, 70, 163-176. http://dx.doi.org/10.1016/S0040-1625(01)00165-2

Khalil, T. M. (2000). Management of technology- the key to competitiveness and wealth creation. Boston: McGraw-Hill.

Klusacek, K. Selection of research priorities - method of critical technologies. [Online] Available: http://www.strast.cz/dokums_raw/unidocoursecriticaltechnologies10291_937.pdf/(July 15, 2012)

Kürtössy, J. (2004). Innovation indicators derived from patent data. Periodica Polytechnica SER. SOC. MAN. SCI., $12,91-101$.

Pappas, C. (1984). Strategic Management of Technology. Journal of Product Innovation and Management, 1, 30-35. http://dx.doi.org/10.1016/S0737-6782(84)80040-5

Parsian Puya Mehr Co. (2009). Membrane Technologies Assessment Report. Tehran: Research and Technology Petrochemical Co.

Pieterse, H. (2001). Telecommunications technology transfer/Diffusion model into rural South Africa. Pretoria: University of Pretoria.

Planning and Development Division of NPC. (2003). Petrochemical Industries Development Strategic Plan Report. Tehran: planning and development division of National Petrochemical Industries Co.

Porter, M. E. (1985). Competitive Advantage. Cambridge: Harvard University Press.

Pretorius, M. W. (2001). Technology assessment in the manufacturing enterprise: a holistic approach. International Association for management of technology (IAMOT), 1-10. [Online] Available: http://logmgt.nkmu.edu.tw/news/articles/Technology\%20Assessment\%20In\%20The\%20Manufacturing\%20Enterpri se.pdf/ (June 10, 2012)

Reitzig, M. (2004). What Do Patent Indicators Really Measure? A Structural Test of 'Novelty' and 'Inventive Step' as Determinants of Patent Profitability. Presented at the DRUID Summer Conference 2004 on Industrial Dynamics, Innovation and Development, 14-16.

United Nations Industrial Development Organization. (2005). Technology foresight manual. Vienna: UNIDO. [Online] Available: http://ictt.by/En/Docs/UNIDOTechForesight/Vol.I_E-book.pdf/(July 24, 2012)

Vernet, A., \& Arasti, M. R. (1999). Linking business strategy to technology strategies: a prerequisite to the R\&D priorities determination international. Journal of Technology Management, 18, $293-307$.

Yu, W. D., \& Lo, S. S. (2009). Patent analysis-based fuzzy inference system for technological strategy planning. Automation in Construction, 18, 770-776. http://dx.doi.org/10.1016/j.autcon.2009.03.003 
Table 1. Comparison between TS techniques

\begin{tabular}{|c|c|c|c|c|}
\hline Method & Input & Process & Output & Reference \\
\hline Critical technologies & $\begin{array}{l}\text { Feasibility, } \\
\text { attractiveness, and list } \\
\text { of areas of technologies }\end{array}$ & $\begin{array}{l}\text { Feasibility } \\
\text { attractiveness matrix }\end{array}$ & $\begin{array}{l}\text { List of critical } \\
\text { technologies }\end{array}$ & (UNIDO, 2005) \\
\hline $\begin{array}{l}\text { Technology } \\
\text { planning approach } \\
\text { (decision matrix) }\end{array}$ & $\begin{array}{l}\text { important technologies, } \\
\text { ability, and } \\
\text { attractiveness }\end{array}$ & $\begin{array}{l}\text { Ability - attractiveness } \\
\text { matrix }\end{array}$ & $\begin{array}{l}\text { Four types of TS in } \\
\text { each important } \\
\text { technology }\end{array}$ & $\begin{array}{l}\text { (Tassel, 1983; Morin, } \\
\text { 1985; Vernet et al, } 1999 \\
\text { cited by Ghazinoory et al, } \\
\text { 2009) }\end{array}$ \\
\hline $\begin{array}{l}\text { Technological } \\
\text { SWOT analysis }\end{array}$ & $\mathrm{S}, \mathrm{W}, \mathrm{O}, \mathrm{T}$ & SWOT Matrix & TSs & (Cardullo, 1996) \\
\hline $\begin{array}{l}\text { National } \\
\text { nanotechnology } \\
\text { strategy in Iran }\end{array}$ & $\begin{array}{l}\text { Country's technological } \\
\text { vision and goals, list of } \\
\text { areas of technologies, } \\
\text { STEEP, attractiveness, } \\
\text { and capability }\end{array}$ & $\begin{array}{l}\text { SWOT matrix, } \\
\text { Capability } \\
\text { attractiveness matrix }\end{array}$ & TSs & (Ghazinoory et al, 2009) \\
\hline $\begin{array}{l}\text { Technology } \\
\text { sourcing decision }\end{array}$ & $\begin{array}{l}\text { Cost of technology } \\
\text { development, strategic } \\
\text { impact of technology }\end{array}$ & $\begin{array}{l}\text { Matrix presented by } \\
\text { AD Little based on the } \\
\text { strategic impact of } \\
\text { technology and the } \\
\text { anticipated cost of } \\
\text { technology } \\
\text { development. }\end{array}$ & $\begin{array}{l}\text { Three technology } \\
\text { sourcing decisions }\end{array}$ & (Floyd, 1998) \\
\hline $\begin{array}{l}\text { Booz-Allen } \quad \& \\
\text { Hamilton } \\
\text { methodology }\end{array}$ & $\begin{array}{l}\text { list of areas of } \\
\text { technologies, } \\
\text { technology importance, } \\
\text { position of technology, } \\
\text { business attractiveness, } \\
\text { and position of business }\end{array}$ & $\begin{array}{l}2 \text { matrixes: technology } \\
\text { and business }\end{array}$ & $\begin{array}{l}\text { Investment } \\
\text { prioritization }\end{array}$ & (Pappas, 1984) \\
\hline Chiesa's model & $\begin{array}{l}\text { List of technologies and } \\
\text { their applications }\end{array}$ & $\begin{array}{l}\text { Technology } \\
\text { application matrix }\end{array}$ & $\begin{array}{l}\text { five TSs, three main } \\
\text { decisions (selection, } \\
\text { acquisition, and } \\
\text { timing) }\end{array}$ & (Chiesa, 1996; 2001) \\
\hline $\begin{array}{l}\text { Burgelman et al's } \\
\text { model }\end{array}$ & Forces that shape TS & $\begin{array}{l}\text { Model of forces that } \\
\text { shape TS }\end{array}$ & $\begin{array}{l}\text { three main decisions } \\
\text { (selection, } \\
\text { acquisition and } \\
\text { timing) }\end{array}$ & (Burgelman, 2001) \\
\hline A. D. Little's model & $\begin{array}{l}\text { list of the technologies, } \\
\text { competitive impact of } \\
\text { the technologies, and } \\
\text { the firms' technological } \\
\text { strength }\end{array}$ & $\begin{array}{l}\text { Matrix of Competitive } \\
\text { impact of the } \\
\text { technologies - the } \\
\text { firms technological } \\
\text { Strength }\end{array}$ & TSs & (Arasti et al, 2009) \\
\hline Porter's model & $\begin{array}{l}\text { list of the technologies, } \\
\text { evaluation of the firm's } \\
\text { capabilities and the } \\
\text { required investments } \\
\text { for technology } \\
\text { development }\end{array}$ & $\begin{array}{l}\text { Five forces model and } \\
\text { value chain model }\end{array}$ & $\begin{array}{lr}\text { two main } & \text { decisions } \\
\text { (selection } & \text { and } \\
\text { timing) } & \end{array}$ & (Porter, 1985) \\
\hline $\begin{array}{l}\text { Hax \& Majluf's } \\
\text { model }\end{array}$ & $\begin{array}{l}\text { firm and/or business } \\
\text { strategy, technology } \\
\text { assessment, } \\
\text { internal scrutiny }\end{array}$ & $\begin{array}{l}\text { The model of TS } \\
\text { formulation }\end{array}$ & $\begin{array}{l}\text { three main decisions } \\
\text { (selection, } \\
\text { acquisition and } \\
\text { timing) }\end{array}$ & (Hax and Majluf, 1996) \\
\hline McKinsey's Model & $\begin{array}{l}\text { prospects for increased } \\
\text { productivity and } \\
\text { prospects for increased } \\
\text { yield }\end{array}$ & $\begin{array}{l}\text { Matrix of prospects for } \\
\text { increased productivity } \\
\text { and prospects for } \\
\text { increased yield }\end{array}$ & Three main strategy & (Arasti et al, 2009) \\
\hline
\end{tabular}


Table 2. Technological ability and attractiveness indicators

indicators for technological ability in different areas of technology
Access to the required expert human resources in technology (run
fundamental and practical research and develop technology)

Access to required experience, knowledge and information in the technology

Level of education in related fields

Access to required resources in the technology ( $R \& D$, operation and development)

Potential to advance in the fundamental knowledge and technology through relationship with scientific communities

No. of declared patents of technology in petrochemical industry

The capacity of financing from various resources

Commercializing research results in technology field in international market

Supporting by policy making and intellectual property rights legislation

Competitiveness between upstream and downstream industries

Upstream and downstream industries requests of research results

Potential growth of small and medium sized businesses in industry

indicators for technological attractiveness in different areas of technology

Ease of access to the required resources in the technology $(R \& D$, operation, development)

Span of applications achieved by researches in technology

probability of a synergic effect of research in the field of technology with other research areas

The time required to acquire technology and proficiency gain in using it

The comparative position of the new technology vis $-\mathrm{a}-\mathrm{vis}$ the competitive technologies

Position of technology in its own life-cycle

Technology ability to make competitive advantage in production and export

The technology effect on quality improvement and customer satisfaction

Technology influence on job creation

GDP increased by technology

Export volume increased by technology

productivity improved by technology

Market volume influenced by technology

The effect of technology on involvement in international cooperation

Technology influence on providing the social requirements

Technology impact on material effectiveness

Technology impact on energy effectiveness

Environment - friendly effect

Technology importance for human health

Technology importance for the safety of the society

Strategic importance of technology for Iran internationally

Public perception of technological outcomes and their use by
Sources

(Klusacek, 2001; Ghazinoory et al, 2009; Jolly, 2003; Australia CSIRO cited by Parsian Puya Polymer Co., 2009)

(Ghazinoory et al, 2009; Jolly, 2003; Australia CSIRO

cited by Parsian Puya Polymer Co., 2009)

(Klusacek, 2001)

(Klusacek, 2001; Ghazinoory et al, 2009; Jolly, 2003; Australia CSIRO cited by Parsian Puya Polymer Co., 2009)

(Klusacek, 2001; Jolly, 2003)

(Jolly, 2003)

(Klusacek, 2001; Jolly, 2003; Australia CSIRO cited by Parsian Puya Polymer Co., 2009)

(Klusacek, 2001)

(Klusacek, 2001; Jolly, 2003)

(Klusacek, 2001)

\section{Sources}

(Ghazinoory et al, 2009; Australia CSIRO cited by Parsian Puya Polymer Co., 2009)

(Klusacek, 2001)

(Klusacek, 2001; Australia CSIRO cited by Parsian Puya Polymer Co., 2009)

(Ghazinoory et al, 2009)

(Ghazinoory et al, 2009; Jolly, 2003)

(Jolly, 2003)

(Ghazinoory et al, 2009)

(Ghazinoory et al, 2009)

(Klusacek, 2001)

(Klusacek, 2001)

(Klusacek, 2001; Australia CSIRO cited by Parsian Puya Polymer Co., 2009)

(Klusacek, 2001; Australia CSIRO cited by Parsian Puya Polymer Co., 2009)

(Klusacek, 2001; Jolly, 2003; Australia CSIRO cited by Parsian Puya Polymer Co., 2009)

(Klusacek, 2001)

(Klusacek, 2001; Australia CSIRO cited by Parsian Puya Polymer Co., 2009)

(Klusacek, 2001)

(Klusacek, 2001)

(Klusacek, 2001; Australia CSIRO cited by Parsian Puya Polymer Co., 2009)

(Klusacek, 2001; Australia CSIRO cited by Parsian Puya Polymer Co., 2009)

(Klusacek, 2001; Ghazinoory et al, 2009)

(Klusacek, 2001; Australia CSIRO cited by Parsian Puya Polymer Co., 2009)

(Klusacek, 2001; Ghazinoory et al, 2009; Jolly, 2003; 
general public

Compliance with government financial budget allocations for technology development

Compliance with national technological priorities

Patent growth rate in the technology
Australia CSIRO cited by Parsian Puya Polymer Co., 2009)

(Ghazinoory et al, 2009)

(Ghazinoory et al, 2009)

(Ernst, 2003)

\begin{tabular}{|c|c|c|}
\hline products and services & No. & Technologies \\
\hline \multirow[t]{4}{*}{ Nanotechnology } & 1 & Nanoparticles and nanocomposites \\
\hline & 2 & Nanocoatings \\
\hline & 3 & Nanocatalyst \\
\hline & 4 & Nanoapplications for environment \\
\hline \multirow[t]{6}{*}{ Biotechnology } & 5 & Bioremediatiams \\
\hline & 6 & Biological wastewater treatments \\
\hline & 7 & Biodegradables \\
\hline & 8 & Biofeuls \\
\hline & 9 & Biotransformations \\
\hline & 10 & Biosensors \\
\hline \multirow[t]{4}{*}{ Membranes } & 11 & Gas separation \\
\hline & 12 & Liquid separation \\
\hline & 13 & Required membrane synthesis (Gas separation) \\
\hline & 14 & Required membrane synthesis (Liquid separation) \\
\hline \multirow{2}{*}{$\begin{array}{l}\text { Polyethylene } \\
\text { terephthalate }\end{array}$} & 15 & Direct esterification of (PTA) with (EG) and polycondensation \\
\hline & 16 & Transesterification of (DMT) with EG and polycondensation \\
\hline \multirow[t]{3}{*}{ Engineering polymers } & 17 & Two step process \\
\hline & 18 & Phase boundry polymerization (Interfacial process) \\
\hline & 19 & Acrylonitrik butadienn styrene (ABS) \\
\hline \multirow[t]{4}{*}{ Methanol } & 20 & Direct oxidation \\
\hline & 21 & Low pressure \\
\hline & 22 & High pressure \\
\hline & 23 & Liquid phase \\
\hline \multirow[t]{2}{*}{ Olefins and propylene } & 24 & Steam Cracking \\
\hline & 25 & $\mathrm{PDH}$ \\
\hline \multirow[t]{3}{*}{ MTBE } & 26 & Isomerisation process \\
\hline & 27 & Dehydration Process \\
\hline & 28 & MTBE synthesis process \\
\hline \multirow{4}{*}{$\begin{array}{l}\text { Synthesis gas for } \\
\text { ammonia production }\end{array}$} & 29 & Steam reforming \\
\hline & 30 & Reforming with $\mathrm{CO} 2$ \\
\hline & 31 & The partial oxidation \\
\hline & $\begin{array}{l}32 \\
33\end{array}$ & $\begin{array}{l}\text { autothermal reforming } \\
\text { Gas heating reforming }\end{array}$ \\
\hline \multirow{4}{*}{ Urea } & 34 & Flaking \\
\hline & 35 & Prilling \\
\hline & 36 & Granulation \\
\hline & 37 & Crystalization \\
\hline LAB & 38 & $\begin{array}{l}\text { The use of kerosene and after passing through a distillation unit, } \\
\text { desulfurization and the paraffin extracted, converted to normal paraffin is then } \\
\text { converted to LAB }\end{array}$ \\
\hline
\end{tabular}

chemicals and 39 Reaction of ethylene chloride and ammonia agricultural materials 


$\begin{array}{lll}\text { (ethylene Amine) } & 40 & \text { Menu ethanol amine and ammonia } \\ \text { TDI, MDI } & 41 & \text { phosgenation production of (TDI) and (MDI) } \\ & 42 & \text { Carbonation production of (TDI) and (MDI) } \\ \text { Aniline } & 43 & \text { Hydrogenation of Nitrobenzene } \\ \text { Aromatic } & 44 & \text { Catalytic Reforming } \\ & 45 & \text { Aromatics extraction from pyrolysis gasoline } \\ \text { Kaprolaktam } & 46 & \text { production process from phenol } \\ & 47 & \text { Production process from toluene } \\ & 48 & \text { Production process from Cyclohexane } \\ \text { Triple super phosphate } & 49 & \text { DEN } \\ \text { (TSP) } & 50 & \text { Granulation } \\ \text { Sulfuric acid } & 51 & \text { Process of sulphur } \\ \text { Nitric acid } & 52 & \text { Weak nitric acid } 60 \% \\ & 53 & \text { Strong nitric acid } 99 \% \\ \text { Terfetalik asid } & 54 & \text { Parazaylyn catalytic oxidation by air in the vicinity of the bromine catalyst }\end{array}$

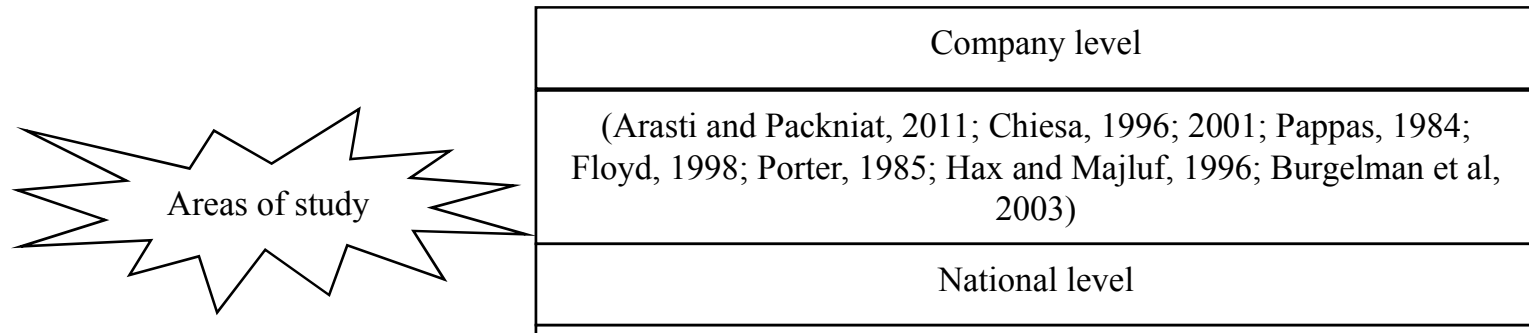

(Ghazinoory et al, 2009; Arasti and Vernet, 1999; Cardullo, 1996)

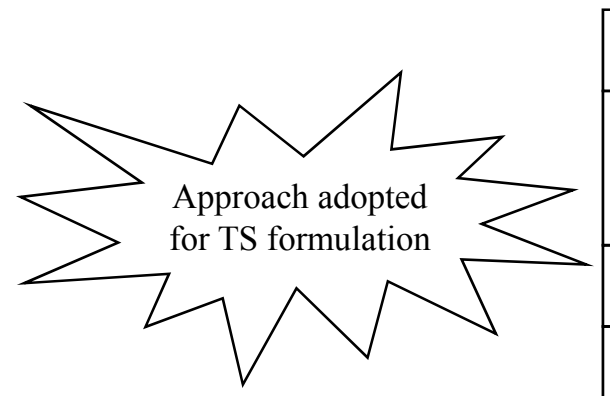

Decision matrices based

(Ghazinoory et al, 1999; Arasti and Vernet, 1999; Cardullo, 1996;

Floyd, 1998; Pappas, 1984; Chiesa, 1996; 2001; Arasti and

Packniat, 2011)

Process based

(Arasti and Packniat, 2011; Porter, 1985; Hax and Majluf, 1996;

Burgelman et al, 2003)

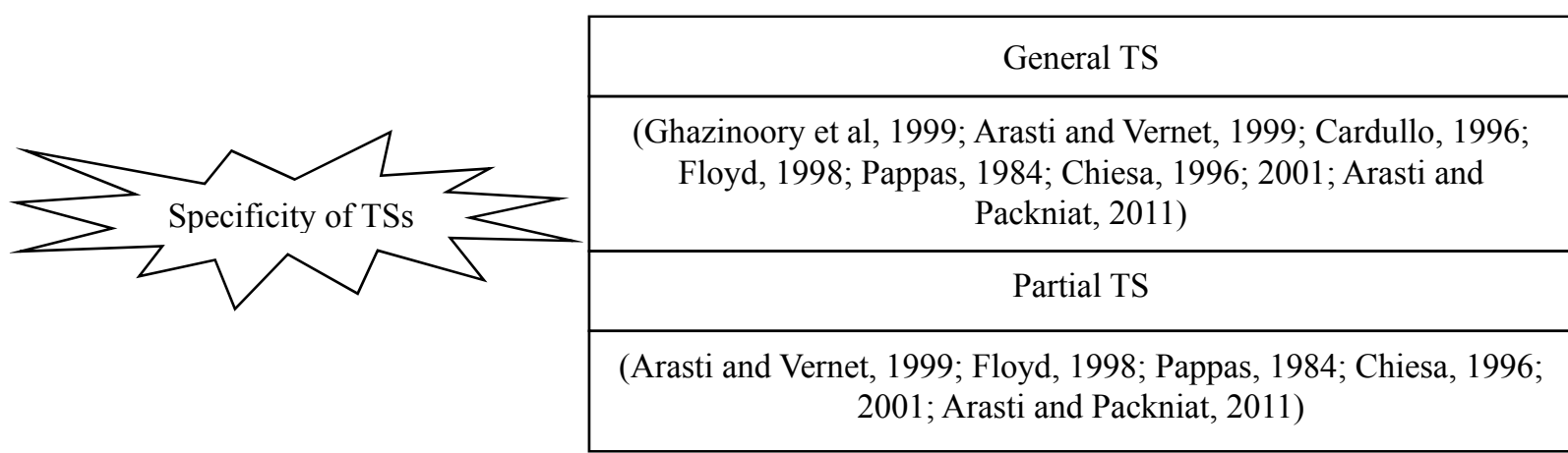

Figure 1. Different perspectives and researches of the models of TS formulation 


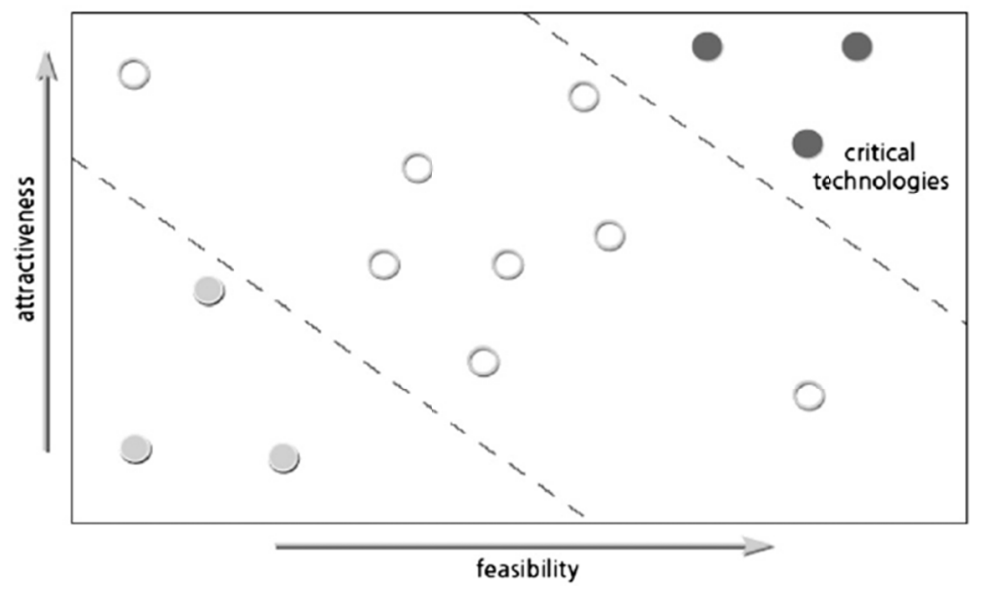

Figure 2. Ranking of technologies based on attractiveness and feasibility (CSIRO cited by Parsian Puya Mehr Co., 2009)

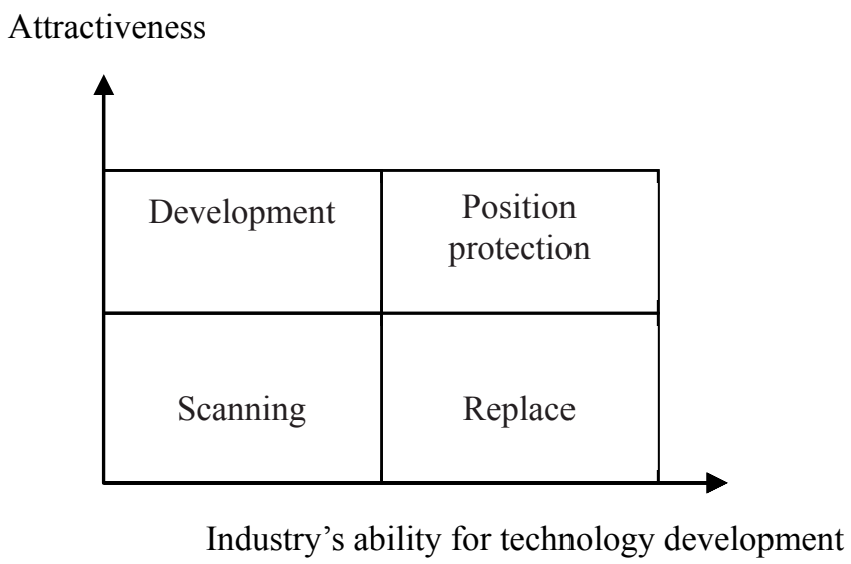

Figure 3. Ability - attractiveness matrix (research driven strategies) (Ghazinoory et al, 2009, 839)

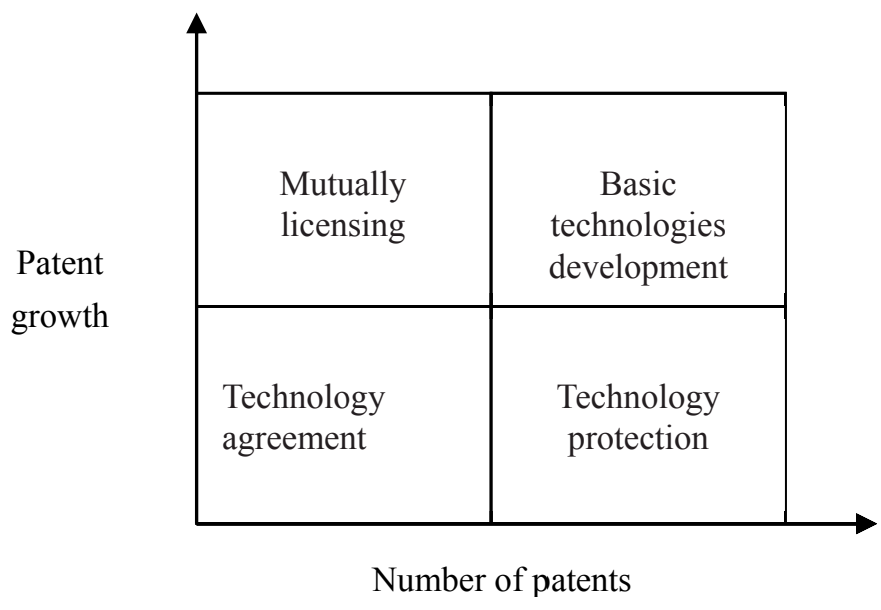

Figure 4. TSs based on patent indicators (Knowledge driven strategies) 


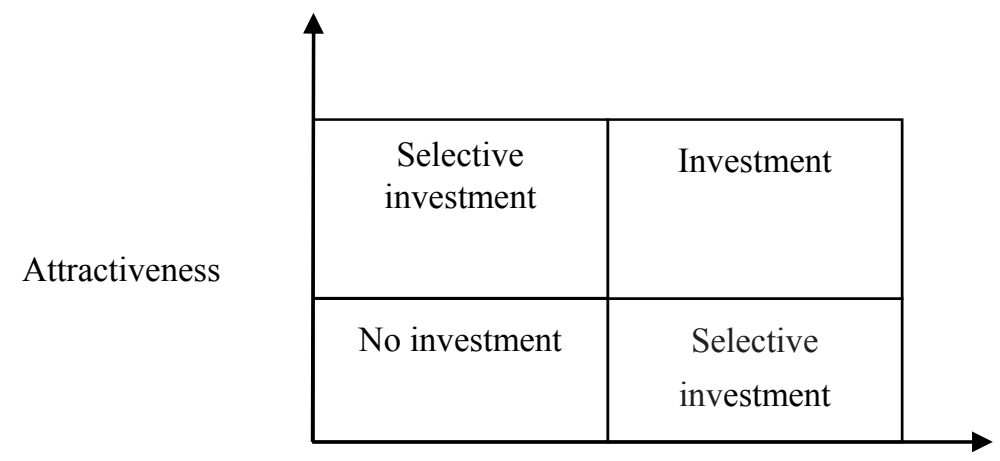

Ability

Figure 5. TSs related to investment (investment driven strategies)

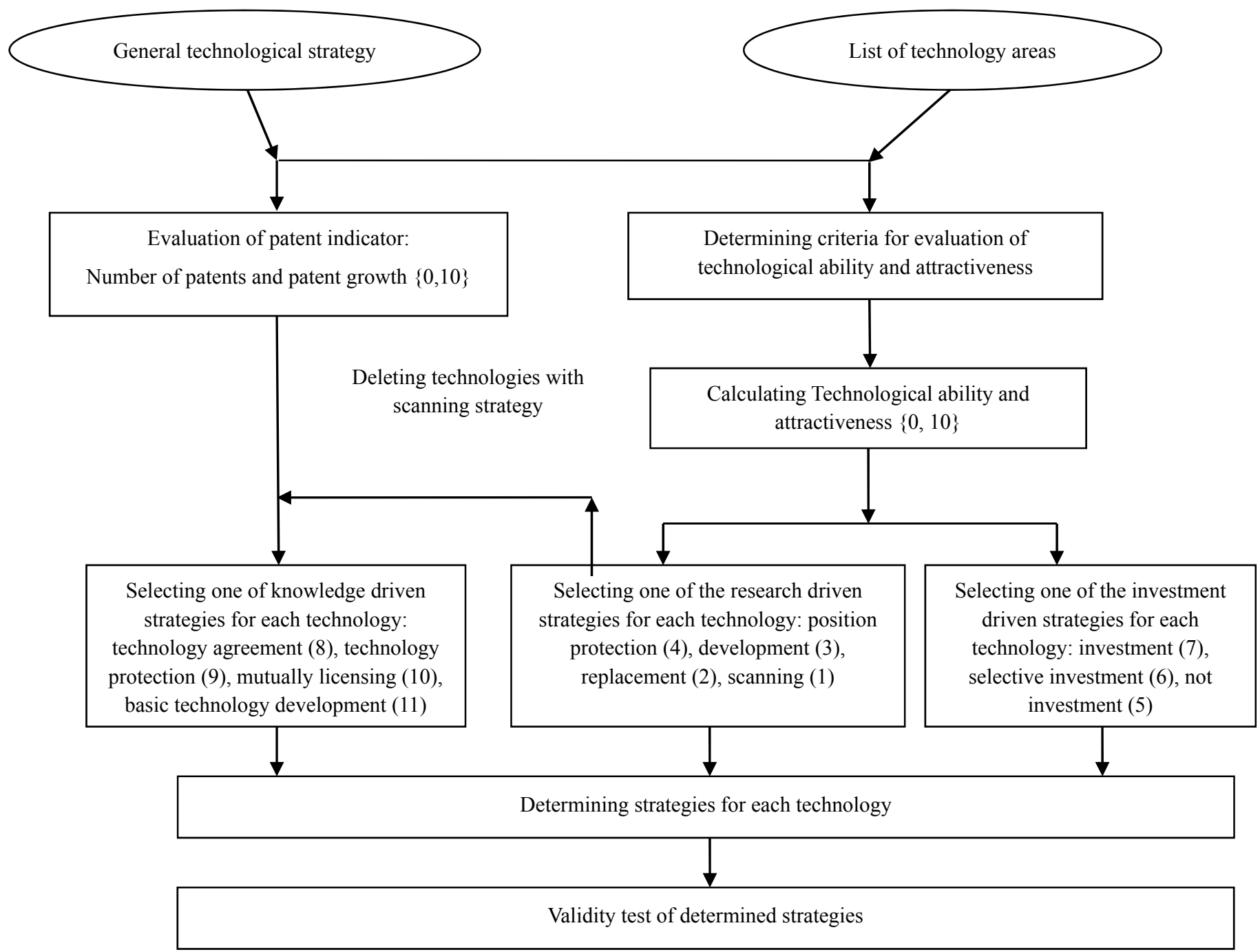

Figure 6. TS model in IPI 


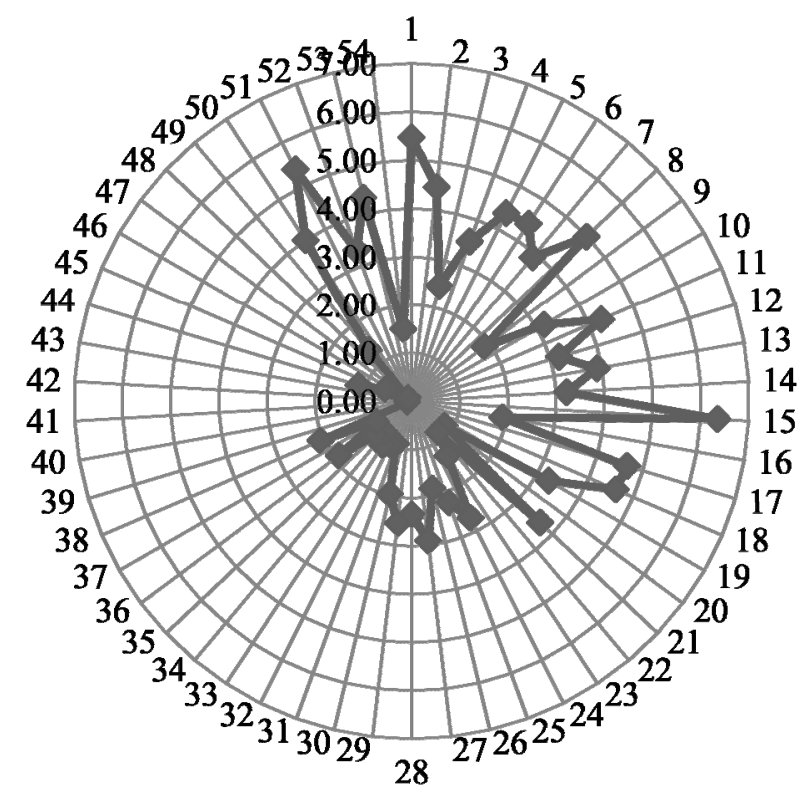

Figure 7. The status of industry's ability for technology development

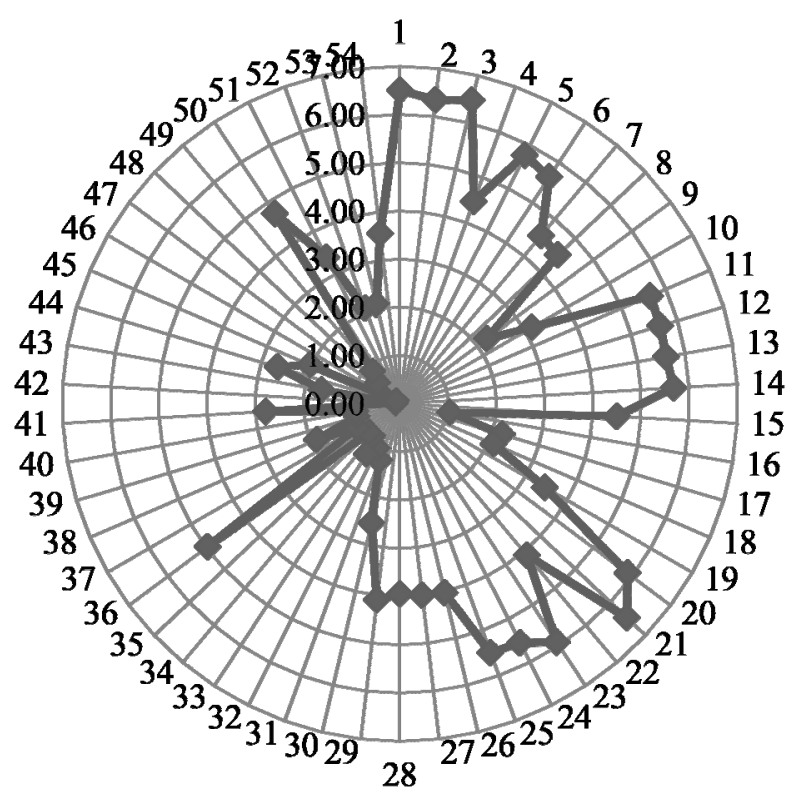

Figure 8 . The status of the attractiveness of the technologies in IPI 


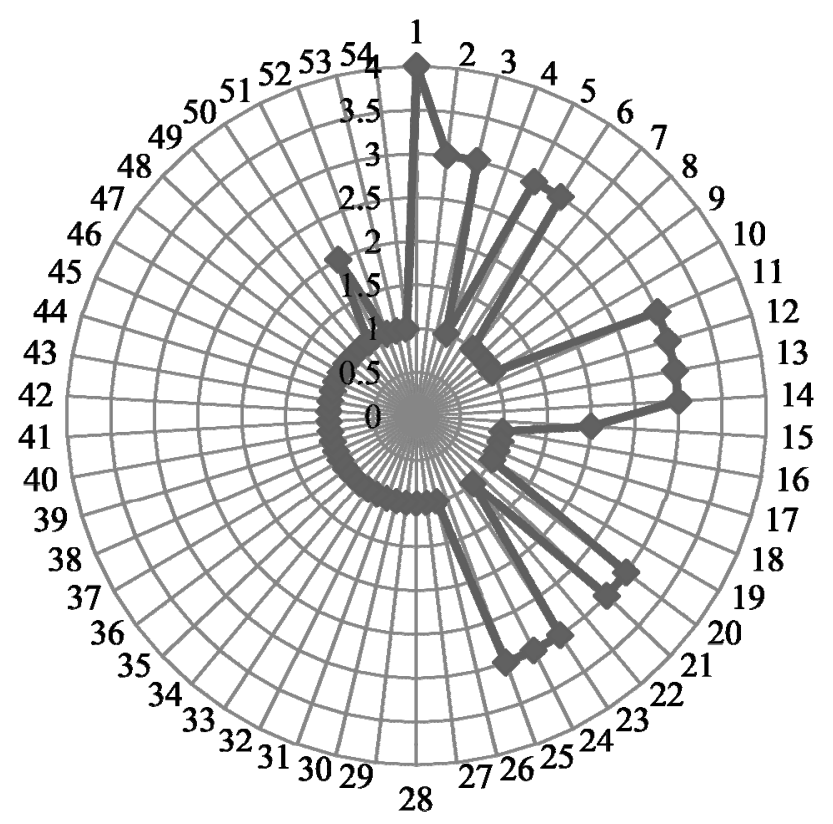

Figure 9. The status of research driven TSs in IPI

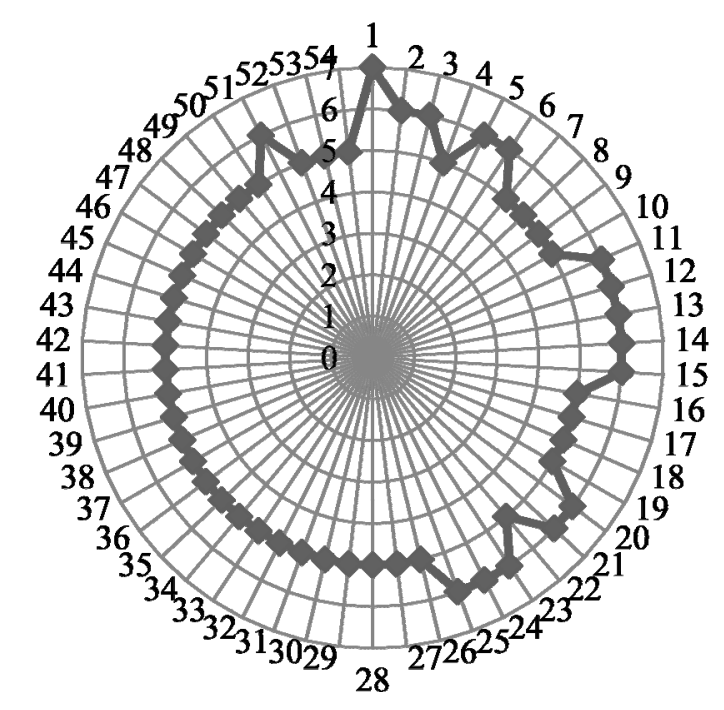

Figure 10. The status of investment driven TSs in IPI 